Marzena Mruk

Uniwersytet Śląski w Katowicach

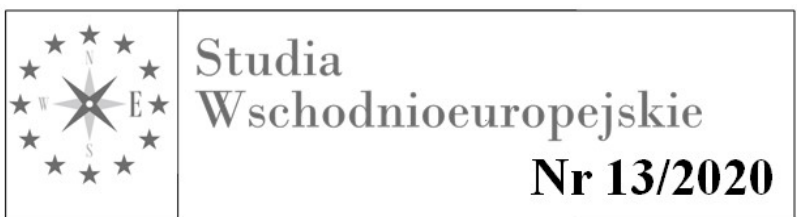

\title{
Czeczenia w XXI wieku, czyli stabilność wewnętrzna Federacji Rosyjskiej a „,niesforna Republika”
}

Zaukaz Północny jest jednym z najbardziej niestabilnych terytoriów obszaru
poradzieckiego i sytuacja $w$ tym regionie stanowi wyzwanie dla bezpieczeństwa międzynarodowego, a w szczególności dla stabilności wewnętrznej Federacji Rosyjskiej. Kluczowe znaczenie w tym kontekście ma Republika Czeczenii, która znalazła się pod panowaniem rosyjskim w połowie XIX wieku i od tamtego czasu dochodziło wielokrotnie do próby podporządkowania jej sobie przez kolejnych carów, Związek Radziecki aż po dzisiejszą Federację Rosyjską. Historia relacji czeczeńsko-rosyjskich jest naznaczona sporami, kryzysami czy też zbrodniami, które determinują obecną sytuację w Czeczenii i jej wpływ na Federację Rosyjską.

Zakończenie zimnej wojny i rozpad Związku Radzieckiego, w tym przykład innych państw poradzieckich: krajów nadbałtyckich, Ukrainy czy państwa Kaukazu Południowego: Armenii, Azerbejdżanu i Gruzji, otworzyły Czeczenom możliwość ponownej walki o utworzenie samodzielnego i niezależnego państwa. Osłabienie Rosji, która utraciła swoją potęgę stała się impulsem dla ruchów narodowowyzwoleńczych na terenie poradzieckim, czego symbolem stało się ogłoszenie niezależności Republiki Czeczenii od Federacji Rosyjskiej w 1991 roku. Moskwa nie mogąc sobie pozwolić na utratę wpływów na Kaukazie Północnym ze względów prestiżowych, podjęła próbę siłowego utrzymania jedności państwa. Dwie następujące po sobie w krótkim czasie wojny czeczeńskie, odpowiednio w 1994 i 1999 roku przyniosły Federacji Rosyjskiej tylko chwilowy spokój i stabilność, a jej skutki odczuwane są do dzisiaj. Obok niestabilności w samym regionie Kaukazu Północnego, wyłonił się również problem bezpieczeństwa energetycznego czy rozwój fundamentalizmu islamskiego, który w przypadku Rosji jest szczególnie niebezpieczny, mając na uwadze jej coraz większą aktywność na Bliskim Wschodzie i całym świecie muzułmańskim.

Temu zagadnieniu poświęcony jest niniejszy artykuł: wpływie sytuacji w Czeczenii w XXI wieku na stabilność wewnętrzną Federacji Rosyjskiej. Głównym pytaniem badawczym zawartym w tym artykule jest: czy wydarzenia w Czeczenii do jakich doszło w przeciągu 
ostatnich dwóch dekad stanowiły zagrożenie dla stabilności wewnętrznej Rosji? Natomiast główną hipotezą tekstu jest stwierdzenie, że nieformalny sojusz zawarty między Władimirem Putinem a rodziną Kadyrowów stanowi element stabilizujący sytuację w Czeczenii i jest fundamentem polityki Kremla wobec „niesfornej” Republiki. W niniejszym artykule w celu analizy powyższego problemu zostały wykorzystane następujące metody badawcze: analiza historyczna, metoda decyzyjna oraz synteza.

Artykuł został podzielony na dwie części. W pierwszej przedstawiony został zarys ogólnej sytuacji w Czeczenii po 2000 roku oraz polityki rządu federalnego, w szczególności administracji Putina wobec Groznego. W drugiej części analizie został postawiony problem wzrostu fundamentalizmu islamskiego w Czeczenii po 2000 roku, ze szczególnym uwzględnieniem znaczenia czeczeńskich czarnych wdów oraz funkcjonowanie tzw. Państwa Islamskiego w wilajecie Kaukazu.

\section{Czeczenia w XXI wieku: zarys sytuacji politycznej. Czeczenizacja polityki rosyjskiej po 1999 roku}

Rozpoczęta jesienią 1999 roku druga wojna w Czeczenii już na początku 2000 roku zmieniła swój charakter z wojny regularnej na działania partyzanckie. W czerwcu tegoż roku ogłoszono oficjalny koniec fazy militarnej, a na czele „niesfornej” republiki stanął Achmed Kadyrow. Oficjalne zakończenie działań zbrojnych oznaczało zmniejszenie zainteresowania Kremla problemem czeczeńskim oraz próbami udowodnienia społeczności międzynarodowej, jak i własnym obywatelom, że sytuacja w Czeczenii ulega stabilizacji pod każdym względem $^{433}$

Od 2002 roku administracja Władimira Putina prowadziła politykę czeczenizacji, czyli uznaniu prorosyjskiego rządu Achmada Kadyrowa i przekazywaniu mu władzy w sposób etapowy, przy jednoczesnym sprzeciwie wobec pokojowych rozmów z partyzanami. Przypadek Kadyrowa jest o tyle ciekawy, że działając po stronie rebeliantów czeczeńskich, już w pierwszych dniach drugiej wojny czeczeńskiej przeszedł na stronę prorosyjską, co zagwarantowało mu uzyskanie w 2000 roku stanowiska szefa cywilnej administracji Czeczenii ${ }^{434}$. Na wiosnę 2003 roku Czeczenia przyjęła nową konstytucje, która określała Republikę Czeczenii jako nieodłączną część Federacji Rosyjskiej, co zostało jednoznacznie

433 A. Łabuszewska, Podsumowanie przemian polityczno-gospodarczych $w$ pierwszej kadencji Władimira Putina. Czeczenia a Rosja: znaczenie kwestii czeczeńskiej dla współczesnej Rosji, Warszawa 2003, s. 30.

${ }^{434}$ M. Falkowski, Czeczenia $i$ Kaukaz Pótnocny po zamachu w Biesłanie [w:] Czeczenia-Rosja. Mity $i$ rzeczywistość, J. Brodowski, M. Smoleń (red.), Kraków 2006, s. 52. 
odebrane przez ludność czeczeńską za zdradę ze strony Kadyrowa, który w zamian za podporządkowanie Republiki Moskwie otrzymywał kolejne zyski. Rząd rosyjski zapowiedział przeprowadzenie w Czeczeni wyborów parlamentarnych i prezydenckich oraz zwiększenia pomocy gospodarczej, niemniej nie zmieniło to nastawienia Czeczenów wobec Kadyrowa, a pogłębiło tylko różnice wewnątrz samej republiki ${ }^{435}$.

Relacje rosyjsko-czeczeńskie uległy znaczącej zmianie 9 maja 2004 roku, gdy podczas obchodów Dnia Zwycięstwa zamordowano prezydenta Republiki, Achamada Kadyrowa, co skutkowało przejęciem tego stanowiska przez Ramzana Kadyrowa ${ }^{436}$. W związku z pogarszającą się sytuacją w Czeczenii, zwłaszcza gospodarczą doszło to nieoficjalnego rozrumienia Kadyrowa z Putinem, wedle którego, dzięki uległości Groznego wobec Moskwy pod względem politycznym, rząd federalny miał rozpocząć finansowanie regionu w celu jego odbudowy ${ }^{437}$. Takie relacje Rosji i Czeczenii można było zatem określić jako „ukryty separatyzm", dzięki któremu Czeczenia mogła realizować swoje interesy należąc jednocześnie do Federacji Rosyjskiej. Poniekąd w zamian za uzyskanie względnie dobrych relacji z rządem rosyjskim, Ramzan Kadyrow od początku sprawowania przez siebie władzy podkreślał swoje dobre relacje z Władminirem Putinem, niejednokrotnie nazywając go swoim mentorem i stworzył swoisty kult rosyjskiego prezydenta w Czeczenii, czego przejawem stały się kolejne place i ulice nazwane jego imieniem ${ }^{438}$. Przyjazne stosunki między Władimirem Putinem a Ramzanem Kadyrowem skutkowały stworzeniem w Republice reżimu autorytarnego zdominowanego przez elitę skupioną wobec Kadyrowa, notorycznie łamiącego prawa człowieka i stosując wszelakie środki terroru wobec obywateli. O pozycji Kadyrowa znaczy fakt, że burmistrz Groznego stwierdził, że „Wszystko co się naprawdę wydarza w Czeczenii, dzieje się według wskazówek Kadyrowa. On odpowiada za wszystko przed ludźmi, Bogiem i prezydentem Rosji ${ }^{4}{ }^{439}$. Sam Kadyrow wielokrotnie powtarzał, że nikt poza prezydentem Federacji Rosyjskiej, nie może ograniczać ani kontrolować jego działań, włączając to parlament, sądy, media czy też opozycja, czego najlepszym przykładem są podejrzenia, co do udziału Kadyrowa w śmierci dziennikarki śledczej, Anny Politkowskiej w 2006 roku oraz obrończyni praw człowieka, Natalii Estemirowej w 2009 roku ${ }^{440}$. Polityka

\footnotetext{
${ }^{435}$ A. Labuszewska, Podsumowanie przemian polityczno-gospodarczych ..., op. cit., s. 31 .

${ }^{436}$ M. Falkowski, Czeczenia między kaukaskim dżihadem a ,ukrytym” separatyzmem, Warszawa 2007, s. 21.

${ }^{437} \mathrm{P}$. Bielecki, Znaczenie relacji rosyjsko-czeczeńskich dla współczesnego bezpieczeństwa międzynarodowego, „Nowa Polityka Wschodnia’' 2018, nr 4, s. 121.

438 P. Olchowska, Prezydentura Ramzana Kadyrowa, https://phavi.umcs.pl/at/attachments/2018/1018/104232-cew-analiza-nr18.pdf (09.07.2020).

${ }^{439}$ U. Halbach, Chechnya's Status within the Russian Federation. Ramzan Kadyrov's Private State and Vladimir Putin's Federal "Power Vertical”, Berlin 2018, s. 13.

${ }^{440} \mathrm{~K}$. Eggert, Opinion: Russia still lives in the shadow of the Chechen war, za :
} 
czeczenizacji przyniosła Rosji wymierne efekty, gdyż udało się uzyskać względny spokój w zbuntowanej Republice, ale kosztowało to Rosję ograniczenie wpływów federalnych na korzyść rodu Kadyrowów ${ }^{441}$.

Wygrana Dmitrija Miedwiediewa w wyborach prezydenckich w 2008 roku oznaczała podjęcie decyzji o kontynuowaniu bądź zmianie polityki rządu federalnego wobec Republiki Czeczenii. Już pierwsze oświadczenie nowo wybranego prezydenta na temat Czeczenii jednoznacznie ukazywało, że zostanie utrzymany kierunek polityki przyjętej przez Władimira Putina na początku dekady. Według Miedwiediewa, działania Ramzana Kadyrowa przyczyniły się do wejścia Czeczeni z fazy odbudowy do fazy rozwoju ${ }^{442}$. Ponadto podjęto decyzję o oficjalnym zakończeniu operacji antyterrorystycznej w Czeczeni marcu 2009 roku, co miało także zakończyć dotychczasową politykę czeczenizacji w takim stylu, w jakim ona była prowadzona do tamtego czasu ${ }^{443}$. Niemniej, sama polityka rządu Miedwiediewa nie skupiała się na problemie czeczeńskim, jak administracja Putina, ale początek drugiej dekady XXI wiek był zdecydowanie spokojniejszym okresem w relacjach czeczeńsko-rosyjskich, co wynikało z odejściem sił czeczeńskich od działań wymierzonych w rosyjskie siły zbrojne, a działania partyzanckie stały się niemal rzadkością. Było to wynikiem licznych podziałów wśród grup opozycyjnych i partyzanckich, które od kilku lat nie potrafiły określić wspólnego stanowiska wobec przyszłości Republiki. Ponadto, ugrupowaniom brakowało jednego przywódcy obdarzonego autorytetem, który mógłby zjednoczyć wszystkich bojowników w walce o niepodległość ${ }^{444}$.

Pod koniec 2014 roku w Groznym ponad 10 tysięcy funkcjonariuszy czeczeńskich służb bezpieczeństwa złożyło przysięgę wierności Władimirowi Putinowi, a Ramzan Kadyrow zapowiedział gotowość walki w imię interesów Federacji Rosyjskiej, gdzie tylko byłoby to konieczne i jednocześnie skrytykował sytuację w innych państwach na obszarze poradzieckim, głównie na Ukrainie oraz bliskowschodnią politykę Stanów Zjednoczonych, szczególnie wobec wojny w Syriii ${ }^{445}$.

Ważnym dla Rosji było zapewnienie bezpieczeństwa podczas Zimowych Igrzysk Olimpijskich w Soczi w 2014 roku. Stanowiło to wyzwanie dla rządu federalnego, gdyż Soczi

\footnotetext{
https://www.dw.com/en/opinion-russia-still-lives-in-the-shadow-of-the-chechen-war/a-50609732 (09.07.2020).

${ }^{441}$ M. Falkowski, Ramzanistan. Czeczeński problem Rosji, Warszawa 2015, s. 12.

${ }^{442}$ M. Vatchagaev, Dmitry Medvedev's Chechnya Policy, za: https://jamestown.org/program/dmitry-medvedevschechnya-policy/ (08.07.2020).

${ }^{443}$ M. Falkowski, Ramzanistan ..., op. cit., s. 10

444 R. Kłaczyński, Republika Czeczenii - sukces czy porażka rosyjskiej polityki wewnętrznej?, „Annales Universitatis Paedagogicae Cracoviensis Studia Politologica', 2014, nr 12, s. 121.

${ }^{445}$ M. Falkowski, Ramzanistan ..., op. cit., s. 23
} 
znajduje się w bliskim sąsiedztwie Republiki Czeczenii, a Doku Umarow, twórca Emiratu Kaukaskiego jeszcze na kilka lat przed rozpoczęciem imprezy, zaczął wzywać bojowników do sabotowania Igrzysk, w tym prowadzeniu ataków na obiekty cywilne. Pomimo iż udało się zapewnić bezpieczeństwo w czasie Igrzysk Olimpijskich, to zagrożenie terrorystyczne zostało odebrane przez rząd federalny bardzo poważnie, szczególnie mając w pamięci wcześniejsze ataki bojowników Kadyrowa, co spowodowało, że nadano mu określenie rosyjskiego Osamy bin Ladena ${ }^{446}$.

Czeczenia odgrywa ważną rolę w budowaniu bezpieczeństwa energetycznego Rosji, gdyż jej głównym surowcem naturalnym jest ropa naftowa. Wskazuje się, że zasoby handlowe Czeczenii są na wyczerpaniu i wynoszą tylko około $60 \mathrm{mln}$ ton, pomimo iż na terenie Republiki znajdą się rezerwy tego surowca odkreślane na ponad $370 \mathrm{mln}$ ton. Głównym problemem w ich wydobyciu są kwestie techniczne i brak odpowiedniej kadry odpowiedzialnej za prowadzenie działań wydobywczych. Czeczenia pod zwierzchnictwem Kadyrowa w 2016 roku wznowiła prace wydobywcze, jednak głównym celem władz jest budowa własnej rafinerii, tak by przyniosła ona znaczące dochody do pudrze tu republiki oraz stworzyła nowe miejsca pracy w celu walki z bezrobociem ${ }^{447}$.

Można zatem zauważyć, że mimo iż wojny czeczeńskie miały miejsce ponad 20 lat temu, to ich skutki nadal są widoczne dla władz Federacji Rosyjskiej. Niepisany sojusz między Putinem a Kadyrowem spowodował funkcjonowanie rządu autorytarnego w Republice czeczeńskiej, gdzie rozwija się prężnie korupcja, nepotyzm, opozycja nie istnieje oraz łamane są podstawowe prawa człowieka.

\section{Wzrost znaczenia fundamentalizmu islamskiego w Czeczenii}

Czeczenia od lat 90. XX wieku była miejscem szczególnego zainteresowania fundamentalistów islamskich, szczególnie saudyjskich wahabitów. Rozwój salafizmu w Czeczenii nastąpił w okresie między pierwszą a drugą wojną czeczeńską, gdy rosyjskie siły specjalne wykorzystywały obecność radykałów islamskich jako pretekstu do prowadzenia operacji zbrojnych w celu zaprowadzenia ładu i bezpieczeństwa w republikach kaukaskich. Dopiero rozpoczęcie operacji antyterrorystycznej przez siły specjalne Rosji, która objęła zarówno Czeczenów walczących o niepodległe państwo, jak i radykalnych islamistów,

\footnotetext{
${ }^{446}$ M. Müller, Chechen terrorist challenges Sochi Olympics, za: https://www.dw.com/en/chechen-terroristchallenges-sochi-olympics/a-17341735 (09.07.2020).

${ }^{447}$ P. Bielecki, Znaczenie relacji rosyjsko-czeczeńskich..., op. cit., s. 123.
} 
zerwała ukrywaną współprace między fundamentalistami a Moskwą ${ }^{448}$. Problemem w relacjach rosyjsko-czeczeńskich był także stosunek poszczególnych przywódców Czeczenii co do roli islamu: Asłan Maschadow opowiadał się za umiarkowaną islamizacją, ale wyłącznie w granicach Republiki Czeczenii; Szamir Basajew i Doku Umarow wyrażali pogląd, że Czeczenia powinna dążyć do zbudowania państwa islamskiego wraz z innymi republikami kaukaskimi ${ }^{449}$.

Salafizm w Czeczenii nabrał szczególnego znaczenia po wydarzeniach z 11 września 2001 roku. Zachód na czele ze Stanami Zjednoczonymi rozpoczął globalną wojnę z terroryzmem w Afganistanie, natomiast Federacja Rosyjska stanęła przed wyzwaniem, jakim było opanowanie trwającego konfliktu w Czeczenii. Pomimo zmiany charakteru prowadzenia działań zbrojnych z regularnej wojny do działań partyzanckich, głównym problemem był wzrost islamizacji w tamtym regionie ${ }^{450}$. Stany Zjednoczone zapraszając Rosję do współpracy w ramach walki z terroryzmem islamskim, niejako dały Moskwie zielone światło do kontynuowania operacji antyterrorystycznej w Czeczenii, dzięki czemu Rosja zaczęła podkreślać swoją rolę pierwszej ofiary międzynarodowego terroryzmu islamskiego i nie musiała już uzasadniać swoich działań zbrojnych w regionie tłumacząc ją swoją aktywnością w ramach współpracy ze Stanami Zjednoczonymi.

23 października 2002 roku Federacja Rosyjska stała się ofiarą bezprecedensowego aktu terrorystycznego dokonanego przez czeczeńskich bojowników. Mowsar Barajew wraz z oddziałem zamachowców-samobójców dokonał ataku (do organizacji którego w późniejszym czasie przyznał się Szamil Basajew) na moskiewski teatr na Dubrowce, podczas którego wzięto blisko 800 osób za zakładników, żądając tym samym opuszczenia Republiki Czeczenii przez siły rosyjskie ${ }^{451}$. Decyzja o dokonaniu ataku na teatr w Moskwie nie była bez znaczenia, gdyż przedstawienie wystawiane wówczas było pierwszym takim przedsięwzięciem, realizowanym na światowym poziomie, a na dodatek odwoływał się do najważniejszych wydarzeń historii Rosji ${ }^{452}$. Rosyjski rząd wykorzystując hasła walki z globalnym terroryzmem stwierdził, że za zamach odpowiadają bojownicy radykalnego dżihadu i podjęto decyzję o interwencji, która zakończyła się licznymi stratami wśród zakładników

\footnotetext{
${ }^{448}$ M. Falkowski, Rosyjski „,Bliski Wschód”: eskalacja konfliktów religijnych na Kaukazie Północnym, za: https://www.osw.waw.pl/sites/default/files/komentarze_207_0.pdf (08.07.2020).

${ }^{449} \mathrm{P}$. Bielecki, Znaczenie relacji rosyjsko-czeczeńskich..., op. cit., s. 121.

${ }^{450}$ Ibidem, s. 120-121.

${ }^{451}$ A. Łabuszewska, Podsumowanie przemian polityczno-gospodarczych ..., op. cit., s. 30.

${ }^{452}$ M. Maciejak, Anatomia konfliktu rosyjsko-czeczeńskiego. Grozy 1994/1995,1999/2000, Zabrze-Tarnowskie Góry 2018, s. 398.
} 
W 2003 roku na spotkaniu z liderami duchowymi Czeczeńskiej Republiki, ówczesny prezydent Rosji Władimir Putin podkreślił, że dla Federacji Rosyjskiej zagrożeniem jest zdecydowanie salafizm, a nie sufizm, który dominuje w Republice Czeczenii i w 2003 roku, czyli między atakiem na teatr na Dubrowce a atakiem na szkołę w Biesłanie, Władimir Putin powiedział że „w Rosji, a szczególnie na Kaukazie, autorytet duchowych liderów był od zawsze bardzo wysoki (...) Wysoko cenimy waszą rolę w ustanowieniu porozumienia między zwolennikami różnych religii, w utrzymaniu stabilności i międzyetnicznej zgody na Północnym Kaukazie w szczególności, ale także w Rosji. Rozumiemy, że pod wieloma względami to właśnie dzięki waszej pozycji, ekstremistom i radykałom nie udała się ideologiczna ekspansja na Północnym Kaukazie. (...) Dzisiaj, kiedy terroryści próbują wykorzystywać religijne wartości dla osiągnięcia daleko niemoralnych celów, wasza twarda postawa jest szczególnie ważna"453. Od 2004 roku nastąpił powrót do sufizmu i rozpoczęto brutalne represje wobec salafitów, która trwa do teraz i często przybiera formę kary śmierci za głoszenie poglądów salafickich, czy też posiadania cech zewnętrznych, takich jak noszenie brody bez wąsów ${ }^{454}$.

Drugim atakiem terrorystycznym przeprowadzonym przez czeczeńskich bojowników Szamila Basajewa był przeprowadzony 1 września 2004 roku zamach na szkołę w Biesłanie, podczas uroczystości rozpoczęcia roku szkolnego. Atak nie miał jednak miejsca w rosyjskiej stolicy, ale w Biesłanie w Osetii Północnej, gdzie większość obywateli to chrześcijanie, którzy nie są uznawani przez Czeczenów za rdzennych mieszkańców Kaukazu Północnego. Uwięziono wówczas blisko 1300 zakładników, gdzie większość stanowiły dzieci, a głównym postulatem terrorystów podobnie jak podczas ataku w moskiewskim teatrze było zakończenie wojny rosyjsko-czeczeńskiej, wycofanie się sił rosyjskich z Czeczeni oraz zwolnienie z więzień rebeliantów zatrzymanych w czerwcu 2004 roku w Inguszetii przez siły federalne. Siły bezpieczeństwa Rosji, tak jak podczas ataku w 2002 roku otrzymały rozkaz do rozpoczęcia operacji odbicia zakładników, która także zakończyła się licznymi stratami wśród zakładników $^{455}$.

Oba zamachy rozpoczęły także debatę nad zjawiskiem dotychczas rzadko spotykanym, czyli kobiecym dżihadem. Zarówno podczas ataku na teatr na Dubrowce, jak i na szkołę w Biesłanie, w ataku terrorystycznym wzięła udział niespotykana na dotychczasową

\footnotetext{
${ }^{453}$ O. Nadskakuła , ,Swoi” czy ,obcy”- stosunek do wyznawców islamu w Rosji [w:] Zachód a świat islamu Zrozumieć Innego, I. Kończak, M. Woźniak (red.), Łódź 2012, s. 53.

${ }^{454}$ M. Falkowski, Rosyjski ,,Bliski Wschód”: eskalacja konfliktów religijnych na Kaukazie Północnym, za: https://www.osw.waw.pl/sites/default/files/komentarze_207_0.pdf(08.07.2020).

${ }^{455}$ J. Kardaś, Federacja Rosyjska wobec pótnocnokaukaskiego terroryzmu, Poznań 2019, s. 140-141.
} 
skalę liczba tzw. czarnych wdów - odpowiednio 19 i 2. Do 2000 roku udział kobiet w działaniach prowadzonych Czeczenów była znikoma, jednak wraz z wzrastającą liczbą ataków wobec ludności cywilnej w Czeczenii oraz wprowadzeniem w 1999 roku w Czeczenii prawa szariatu, nastąpił wzrost aktywności terrorystycznej kobiet czeczeńskich, które budziły strach wśród ludności cywilnej oraz sił bezpieczeństwa. Należy zwrócić uwagę, że czeczeńskie czarne wdowy różnią się od tzw. samotnych wilków charakterystycznych na przykład dla tzw. Państwa Islamskiego, ponieważ Czeczenki decyzję o podjęciu ataku podejmują w wyniku analizy swojej osobistej historii, często nienawiści spowodowanej utratą bliskich podczas wojen rosyjsko-czeczeńskich, a rzadko kiedy jest to tylko motywacja religijna czy też przymus ze strony rodziny lub liderów organizacji islamskich. Szmail Basajew powołał w 2003 roku nawet batalion kobiecy Rijadus Salichin, który w przeciągu kilku lat przeprowadził kilkadziesiąt udanych ataków terrorystycznych wymierzonych w Federację Rosyjską ${ }^{456}$. Aktywność czeczeńskich czarnych dwóch stanowi wyzwanie dla sił bezpieczeństwa Federacji Rosyjskiej, co wynika z faktu, że kobieta z założenia jest odbierana jako osoba słabsza, nieskłonna do wyrządzenia innej osobie krzywdy, ale także kontrola osobista kobiet, szczególnie muzułmanek, w takich miejscach jak lotniska czy dworce jest skomplikowana na ich obyczaje i religię, przez co często ich kontrole są pobieżne, przez co terroryści odbierają kobiety jako idealne wykonawczynie ataków. Właśnie takie podejście do kobiet spowodowało, że 29 marca 2010 roku doszło do kolejnego ataku terrorystycznego w moskiewskim metrze, gdzie dwie czarne wdowy zdetonowały materiały wybuchowe. Do zamachu przyznał się Doku Umarów, który potwierdził, że samobójczynie były związane z Emiratem Kaukaskim. Umarów przyznał się także do ataku terrorystycznego na moskiewskie lotnisko Domodiedowo 24 stycznia 2011 roku $^{457}$. W porównaniu do wcześniejszych ataków, terroryści nie wysunęli żadnych żądań wobec władz rosyjskich, a ich działania miały na celu tylko wzbudzenie strachu wśród społeczeństwa rosyjskiego.

Proces wzmożonej islamizacji Czeczenii nastąpił po 2005 roku i śmierci Asłana Masachadowa, kiedy to Czeczenii zaczęli odchodzić od prowadzenia działań charakterystycznych dla operacji narodowowyzwoleńczych w kierunku stworzenia państwa islamskiego w Federacji Rosyjskiej. W październiku 2007 roku ogłoszono powstanie Emiratu Kaukaskiego na czele z Doku Umarowem, weteranem wojen czeczeńskich, który ogłosił wówczas, że ,koncepcja stworzenia niepodległej Czeczenii zastąpiona została wizją

\footnotetext{
${ }^{456}$ M. Adamczuk, Czeczeńskie kobiety w strategii działania bojowników kaukaskich, „Przegląd Bezpieczeństwa Wewnętrznego" 2013, nr 8, s. 69-77.

${ }^{457}$ J. Kardaś, Federacja Rosyjska wobec pótnocnokaukaskiego..., op. cit., s. 145.
} 
zjednoczonego islamem pankaukaskiego państwa obejmującego cały rosyjski Kaukaz Północny"458. Powstanie Emiratu Kaukaskiego nie przyczyniło się do zjednoczenia w Czeczenii wszystkich ugrupowań biorących udział w życiu publicznym, a wręcz przeciwnie, spowodowało powstanie ugrupowania, które odcinało się od działalności Umarowa i oskarżało go wręcz o współpracę z rządem federalnym ${ }^{459}$. Natomiast, w 2013 roku Czeczenia ogłosiła, że jest republiką islamską, ale jednocześnie jest częścią Federacji Rosyjskiej ${ }^{460}$.

W kontekście rosnącej roli islamu w Czeczenii ważne jest określenie stosunku Ramzana Kadyrowa wobec najważniejszego konfliktu zbrojnego na Bliskim Wschodzie, w który zaangażowana jest Federacja Rosyjska. Decyzja Władimira Putina o interwencji militarnej w Syrii była jednoznaczna z obawą o wzrost radykalizmu islamskiego w Rosji, szczególnie po powstaniu tzw. Państwa Islamskiego w czerwcu 2014 roku, kiedy to kilka tysięcy Rosjan rozpoczęło walkę po stronie kalifatu. Rosja dokonując interwencji w ogarniętej wojnie Syrią dążyła do nie tyle zniszczenia tzw. Państwa Islamskiego, ale do zniwelowania możliwości ${ }^{461}$. Dla Rosji aktywność bojowników czeczeńskich w szeregach tzw. Państwa Islamskiego jest zagrożeniem dla bezpieczeństwa wewnętrznego oraz po części zdradą państwa, natomiast dla władz czeczeńskich wyjazd kilku tysięcy czeczeńskich fundamentalistów do Syrii i Iraku było odbierane jako pozbycie się niejako problemu, jakim mogliby być ambitni radykałowie, którzy chcieli by przejąć władzę w Groznym. Ponadto, od 2013 roku zaczęła słabnąć Emiratu Kaukaskiego, na czele którego po śmierci Umarowa stanął Ali Abu Muhammad al-Dagestani, który został pierwszym nieczeczeńskim przywódcą Emiratu oraz był zwolennikiem Al-Kaidy. Niemniej, jego władza w Emiracie trwała niecały rok, ponieważ już w 2014 roku został on zamordowany przez siły rosyjskie ${ }^{462}$. Spowodowało to wzrost liczby bojowników składających przysięgę wierności tzw. Państwu Islamskiemu. W czerwcu 2015 roku utworzono Wilajat Kaukazu, który stanowił zmianę kierunku działań czeczeńskich bojowników. Dotychczas byli oni skupieni na walce z siłami rosyjskimi, a wchodząc w szeregi samozwańczego kalifatu, stali się częścią globalnego dżihadu przeciwko niewiernym. Paradoksalnie, powstanie tzw. Państwa Islamskiego przyczyniło się do rozpoczęcia rywalizacji między nim a Emiratem Kaukaskim, przez co władze federalne dzięki wyrokowi

\footnotetext{
${ }^{458}$ R. Kłaczyński, Republika Czeczenii - sukces czy porażka ..., op. cit., s. 119-120

${ }^{459}$ P. Grochmalski, Elity polityczne Czeczenii: historia i wspótczesność [w:] Kaukaz: mechanizmy legitymizacji $i$ funkcjonowania elit politycznych. Tom 7, T. Bodio (red.), Warszawa 2012, s. 297.

460 J. Kardaś, Federacja Rosyjska wobec pótnocnokaukaskiego..., op. cit., s. 96.

${ }^{461} \mathrm{P}$. Bielecki, Znaczenie relacji rosyjsko-czeczeńskich..., op. cit., s. 131-132.

${ }^{462}$ A. Borchevskaya, The Future of Chechens in ISIS, za:

https://www.washingtoninstitute.org/uploads/Documents/opeds/Borshchevskaya_20171009-HSI.pdf (10.07.2020).
} 
Sądu Najwyższego z 29 grudnia 2014 roku stwierdzającym o uznaniu kalifatu za organizację terrorystyczną, mogły swobodnie używać siły wobec obu organizacjom pod hasłem walki z terroryzmem $^{463}$.

Od kilku lat Ramzan Kadyrow starał się także pełnić łącznika w relacjach między rządem federalnym a państwami muzułmańskimi, nagłaśniając między innymi operację sprowadzenia kaukaskich dzieci z obywatelstwem rosyjskim z terenów Syrii i Iraku, które urodziły się na terytoriach tzw. Państwa Islamskiego ${ }^{464}$. Niemniej, jego ambicje polityczne spowodowały, że zaczął przekładać własne interesy oraz interesy Czeczeni nad federacji rosyjskiej i samodzielnie inicjuje spotkania z ważnymi politykami i biznesmenami z państw bliskowschodnich, szczególnie tych znad Zatoki Perskiej.

Od 2017 roku można zauważyć w Czeczenii politykę powrotu do szeroko pojętej tradycji czeczeńskiej, w tym powrotu do pokojowej odmiany islamu jaką jest sufizm, którą próbuje się połączyć z nowoczesnym patriotyzmem. Niemniej, trudno nie wspomnieć o funkcjonowaniu w Czeczenii policji religijnej czy informacjach o budowie obozu dla osób o orientacji homoseksualnej, która jak wiadomo, jest w islamie uznawana za grzech, który należy karać ${ }^{465}$.

Pomimo iż Czeczenia jest częścią składową Federacji Rosyjskiej i obowiązuje w niej rosyjska wykładnia prawa oraz system sądowniczy, to są one jawnie ignorowane i stosuje się w ich miejsce prawo wyznaniowe, na przykład wielożeństwo, ograniczenia w funkcjonowaniu administracji w czasie ramadanu, ograniczenia w handlu używkami czy też konieczność noszenia przez kobiety islamskich strojów ${ }^{466}$.

\section{Wnioski}

Problem czeczeński w ostatnich latach przestał być jednym z głównych tematów podejmowanych przez społeczność międzynarodową, która uznała go za sprawę wewnętrzną Rosji, a jedynym państwem, które uznało państwowość Czeczenii w 2000 roku był rząd talibów w Afganistanie ${ }^{467}$. Spowodowało to, że diaspory czeczeńskie, głównie w Europie straciły możliwość oddziaływania na przywódców europejskich do wykorzystywania kwestii

\footnotetext{
${ }^{463}$ J. Kardaś, Federacja Rosyjska wobec pótnocnokaukaskiego ..., op. cit., s. 163-165. 464 W. Górecki, M. Domańska, Polityka zagraniczna Rosji - koncesje wobec Kadyrowa, za: https://www.osw.waw.pl/pl/publikacje/analizy/2017-09-06/polityka-zagraniczna-rosji-koncesje-wobeckadyrowa (10.07.2020).

465 P. Olchowska, Prezydentura Ramzana Kadyrowa, za: https://phavi.umcs.pl/at/attachments/2018/1018/104232-cew-analiza-nr18.pdf (09.07.2020).

466 M. Falkowski, Ramzanistan ..., op. cit., s. 19.

467 P. Olchowska, Społeczne konstrukcja problemu niepodległości Czeczenii, Toruń 2018, s. 280.
} 
Czeczenii w prowadzeniu polityki wobec Moskwy i wywierania na nią jakiegokolwiek wpływu.

Polityka Federacji Rosyjskiej wobec Republiki Czeczeni w XXI wieku w kontekście religijnym jest niejako kontynuacją niekonsekwentnego stanowiska Moskwy wobec Groznego, jeszcze z okresu zimnowojennego, gdy to władze radzieckie doceniały potencjał sił bojowników islamskich z Czeczenii, w tym włączanie ich do walk między innymi podczas wojny w Afganistanie trwającej od grudnia 1979 roku. Stworzenie precyzyjnego stanowiska Rosji wobec problemu czeczeńskiego pozwoli stworzyć władzom federalnym na utworzenie jednolitej polityki wobec wszystkich republik północnokaukaskich, w których pogarszająca się sytuacja wynikająca $\mathrm{z}$ różnic religijnych, etnicznych czy też rządzeniu przez skorumpowanych polityków, może przyczynić się do rozprzestrzeniania destabilizacji bezpieczeństwa już nie tylko w innych regionach Federacji Rosyjskiej, ale innych państwach regionu, które ciągle znajdują się na drodze rozwoju po upadku Związku Radzieckiego.

Problem islamizacji w Czeczenii wpływa na politykę Rosji wobec innych państw muzułmańskich $\mathrm{w}$ regionie i utrata $\mathrm{w}$ niej wpływów mogłaby spowodować zwiększenie zagrożenia terrorystycznego na terytorium całej Federacji Rosyjskiej. W najgorszym dla Rosji scenariuszu, jakim byłoby uzyskanie przez Republikę Czeczenii niepodległości, inne republiki, w których dominuje islam czyli Inguszetia i Dagestan mogłyby odebrać to jako impuls do podjęcia podobnych działań ${ }^{468}$. Czeczenia dzięki swojemu położeniu geopolitycznemu ma kluczowe znaczenie dla polityki zagranicznej Rosji, gdyż daje możliwość budowania wpływów w Azji Centralnej oraz Bliskim Wschodzie, co pozwala Moskwie na odbudowywanie pozycji mocarstwowej uzyskanej po drugiej wojnie światowej.

Wzrost fundamentalizmu islamskiego na Kaukazie Północnym, szczególnie w Czeczenii przyczynił się w XXI wieku do zjawiska jakim jest islamofobia, której szczególną odmianą jest kaukazofobia przejawiająca się zachowaniami rasistowskimi, nacjonalistycznymi i ksenofobicznymi wobec diaspory czeczeńskiej zamieszkującej innej regiony Federacji Rosyjskiej, przede wszystkim Moskwy ${ }^{469}$. Propaganda mediów spowodowała, że Czeczeni zamiast asymilować się ze społeczeństwem rosyjskim, żyją w zamkniętych osiedlach dużych miast, unikając kontaktu $\mathrm{z}$ światem zewnętrznym ${ }^{470}$, co spowodowało, że zostali odbierani wśród Rosjan jako potencjalny terrorysta, morderca i

\footnotetext{
${ }^{468} \mathrm{P}$. Bielecki, Znaczenie relacji rosyjsko-czeczeńskich..., op. cit., s. 123.

${ }^{469}$ A. Łabuszewska, Podsumowanie przemian polityczno-gospodarczych ..., op. cit., s. 35-36.

470 A. Martofel, Rosyjski „Bliski Wschód”: religijne i spoleczno-polityczne uwarunkowania rozwoju fundamentalizmu islamskiego na Kaukazie Pólnocnym po upadku Związu Radzieckiego, „Nowy Prometeusz" 2018, nr 12, s. 42.
} 
porywacz, co skutkowało takimi sytuacjami, że mieszkańcy Moskwy obawiali się robienia zakupów w sklepach czy straganach prowadzonych przez ludność czeczeńską w obawie przed potencjalnym zatruciem.

Pokój zawarty w Czeczenii dzięki paktowi Kadyrow-Putin jest bardzo kruchy. Ramzan Kadyrow w ciągu kilkunastu lat swojej władzy zdążył stworzyć sobie siły kilkudziesięciu bardzo dobrze uzbrojonych i wyszkolonych bojowników, a gdyby doszło do odsunięcia jego od władzy lub nagłego zniknięcia, to Władimir Putin stanął by przed koniecznością kolejnej konfrontacji zbrojnej w Czeczenii, która zdecydowanie by się różniła od wojen z lat 90. XX wieku ${ }^{471}$. Problemem w ustabilizowaniu sytuacji w Czeczenii dla władz federacji rosyjskiej jest to, że funkcjonują trzy różne ośrodki sprawowania władzy i każdy z nich uważa się za prawowitego i jedynego przedstawiciela Czeczenów: ugrupowanie Kadyrowa, zwolennicy Emiratu Kaukazu oraz grupa Czeczenów na emigracji. Polityka czeczenizacji rozpoczęta przez Władimira Putina spowodowała to, że w granicach Federacji Rosyjskiej powstał praktycznie samo stanowiący o sobie twór o całkowicie innej kulturze i cywilizacji i mimo iż oficjalne jest częścią państwa rosyjskiego, to stworzył swój własny hermetyczny świat, do którego trudno się dostać władzom centralnym.

\section{Streszczenie:}

Głównym pytaniem badawczym zawartym w tym artykule jest: czy wydarzenia w Czeczenii do jakich doszło w przeciągu ostatnich dwóch dekad stanowiły zagrożenie dla stabilności wewnętrznej Rosji? Główną hipotezą tekstu jest natomiast stwierdzenie, że nieformalny sojusz zawarty między Władimirem Putinem a rodziną Kadyrowów stanowi element stabilizujący sytuację w Czeczenii i jest fundamentem polityki Kremla wobec „niesfornej” Republiki. W pierwszej części artykułu przedstawiony został zarys ogólnej sytuacji w Czeczenii po 2000 roku oraz polityki rządu federalnego, w szczególności administracji Putina wobec Groznego. W drugiej części analizie został postawiony problem wzrostu fundamentalizmu islamskiego w Czeczenii po 2000 roku, ze szczególnym uwzględnieniem znaczenia czeczeńskich czarnych wdów oraz funkcjonowanie tzw. Państwa Islamskiego w wilajecie Kaukazu.

\section{Słowa kluczowe:}

radziecki Azerbejdżan, współczesna proza azerbejdżańska, Vaqif Sultanlı, bohater literacki, kategorie czasu i miejsca

\section{Keywords:}

\footnotetext{
${ }^{471}$ M.H. Van Herpen, Wojny Putina: Czeczenia, Gruzja, Ukraina 2014, Warszawa 2014, s. 309.
} 
Soviet Azerbaijan, contemporary Azerbaijani prose, Vagif Sultanl1, a character in literature, the categories of time and place.

\section{Bibliografia:}

1. Adamczuk M., Czeczeńskie kobiety w strategii działania bojowników kaukaskich, „Przegląd Bezpieczeństwa Wewnętrznego” 2013, nr 8.

2. Bielecki P., Znaczenie relacji rosyjsko-czeczeńskich dla wspótczesnego bezpieczeństwa międzynarodowego, „Nowa Polityka Wschodnia”, 2018, nr 4, s. 121.

3. Borchevskaya A., The Future of Chechens in ISIS, za: https://www.washingtoninstitute.org/uploads/Documents/opeds/Borshchevskaya_2017 1009-HSI.pdf (10.07.2020).

4. Eggert K., Opinion: Russia still lives in the shadow of the Chechen war, za :

5. https://www.dw.com/en/opinion-russia-still-lives-in-the-shadow-of-the-chechenwar/a-50609732 (09.07.2020).

6. Falkowski M., Czeczenia i Kaukaz Północny po zamachu w Biesłanie [w:] CzeczeniaRosja. Mity i rzeczywistość, J. Brodowski, M. Smoleń (red.), Kraków 2006.

7. Falkowski M., Czeczenia między kaukaskim dżihadem a ,ukrytym” separatyzmem, Warszawa 2007.

8. Falkowski M., Ramzanistan. Czeczeński problem Rosji, Warszawa 2015.

9. Falkowski M., Rosyjski „Bliski Wschód”: eskalacja konfliktów religijnych na Kaukazie

Pólnocnym,

za: https://www.osw.waw.pl/sites/default/files/komentarze_207_0.pdf(08.07.2020).

10. Górecki W., Domańska M., Polityka zagraniczna Rosji - koncesje wobec Kadyrowa, za: https://www.osw.waw.pl/pl/publikacje/analizy/2017-09-06/polityka-zagranicznarosji-koncesje-wobec-kadyrowa (10.07.2020).

11. Grochmalski P., Elity polityczne Czeczenii: historia i współczesność [w:] Kaukaz: mechanizmy legitymizacji i funkcjonowania elit politycznych. Tom 7, T. Bodio (red.), Warszawa 2012.

12. Halbach U., Chechnya's Status within the Russian Federation. Ramzan Kadyrov's Private State and Vladimir Putin's Federal "Power Vertical", Berlin 2018, s. 13.

13. Kardaś J., Federacja Rosyjska wobec pótnocnokaukaskiego terroryzmu, Poznań 2019.

14. Kłaczyński R., Republika Czeczenii - sukces czy porażka rosyjskiej polityki wewnętrznej?, „Annales Universitatis Paedagogicae Cracoviensis Studia Politologica"' 2014, nr 12.

15. Łabuszewska A., Podsumowanie przemian polityczno-gospodarczych $w$ pierwszej kadencji Władimira Putina. Czeczenia a Rosja: znaczenie kwestii czeczeńskiej dla współczesnej Rosji, Warszawa 2003.

16. Maciejak M., Anatomia konfliktu rosyjsko-czeczeńskiego. Grozy 1994/1995, 1999/2000, Zabrze-Tarnowskie Góry 2018. 
17. Martofel A., Rosyjski „Bliski Wschód”: religijne i społeczno-polityczne uwarunkowania rozwoju fundamentalizmu islamskiego na Kaukazie Pólnocnym po upadku Zwiazku Radzieckiego, „Nowy Prometeusz" 2018, nr 12.

18. Müller M., Chechen terrorist challenges Sochi Olympics, za: https://www.dw.com/en/chechen-terrorist-challenges-sochi-olympics/a-17341735 (09.07.2020).

19. Nadskakuła O., „Swoi” czy ,obcy” - stosunek do wyznawców islamu w Rosji [w:] Zachód a świat islamu - Zrozumieć Innego, I. Kończak, M. Woźniak (red.), Łódź 2012.

20. Olchowska P., Prezydentura Ramzana Kadyrowa, za: https://phavi.umcs.pl/at/attachments/2018/1018/104232-cew-analiza-nr18.pdf (09.07.2020).

21. Olchowska P., Społeczne konstrukcja problemu niepodległości Czeczenii, Torun 2018.

22. Van Herpen M.H., Wojny Putina: Czeczenia, Gruzja, Ukraina 2014, Warszawa 2014.

23. Vatchagaev M., Dmitry Medvedev's Chechnya Policy, za: https://jamestown.org/program/dmitry-medvedevs-chechnya-policy/ (08.07.2020). 